\title{
Physical environment of drumlin formation
}

\author{
Carrie J. Patterson \\ Minnesota Geological Survey, University of Minnesota, St. Paul, Minnesota 55114, U.S.A. \\ ROGER LEB. HOOKE \\ Department of Geology and Geophysics, University of Minnesota, Minneapolis, Minnesota 55455, U.S.A.
}

\begin{abstract}
Review of published descriptions of drumlin fields suggests that the following conditions are important to drumlin growth: (1) compressive longitudinal and possibly extending transverse strain rates in the ice, (2) thin ice such as occurs near the glacier margin, and (3) high pore-water pressure in the subglacial sediments. Most drumlin fields display all of these, and no fields of well-developed drumlins were found that did not. On the other hand, the lithology of drumlin-forming sediment appears not to be important in promoting drumlin growth, since it varied widely, nor are the lithology and large-scale topography of the bed.
\end{abstract}

\section{INTRODUCTION}

In order to define the physical conditions under which drumlins form, we have studied published descriptions of drumlin fields and determined, wherever possible: (1) the nature of the large-scale bed topography on which the drumlins are found, (2) the quality of drumlin development, (3) the spatial organization of individual drumlins in a field, (4) the characteristics of the material in the drumlins and substrate, (5) the time of drumlin formation, (6) the basal ice conditions at the time of drumlin formation, (7) the sense of strain in the ice (e.g. compressive or extending), and (8) the hydrologic conditions of the bed. We emphasize that we do not propose a model of drumlin formation, but rather attempt to define the range of physical conditions under which well-developed drumlins have formed.

Physical conditions that are always or nearly always observed in drumlin fields suggest factors that should be considered in any general theory of drumlin formation. In the same vein, physical conditions that differ appreciably between fields are presumably less important.

This study is an initial phase of an investigation of the hypothesis that there is an ice-flow instability capable of creating drumlins. Our suspicion is that when unstable preconditions are perturbed, forces are set up that cause a departure from the original state (Nayfeh, 1993). For example, a bump on the bed, represented by the drumlin cores that are often observed, might set up a pressure distribution or flow pattern that results in erosion adjacent to the bump or deposition over it, or both. For a drumlin to form, this perturbation not only must be present but must grow so that the resulting landform exceeds the height of the original obstacle.

\section{PRESENTATION OF DATA}

Table 1 summarizes many of the characteristics investigated. Throughout the paper, drumlin fields are referred to by their numbers in this table. A lower-case superscript following a cited field number identifies a specific source. Some of the characteristics chosen for study were not usually described in the literature or were not easily measured. Others are based on necessarily indirect evidence; these characteristics are discussed but do not appear in the table. Space limitations required a selected reference list; a more complete list of drumlin references can be obtained (Menzies, 1984; Patterson, 1989).

\section{Drumlin quality}

A subjective rating of quality was assigned to the drumlin fields to indicate the topographic expression and completeness of the best landforms in a given field. The rating ranges from 1 to 3 ; a rating of 1 means that the landforms are well-formed and distinct and 3 means that they are faint and indistinct.

Drumlins vary in length and width between fields and also within a field. However, a single form invariably dominates each area of the field, and the change to another shape is gradual. The shape has been said to vary according to topography, position with respect to the boundaries of the field, the amount of drift available, ice velocity, strain in the ice, and the drumlin-forming and substrate materials. Such situations are not documented frequently enough, however, to show that a causal relationship exists.

Drumlin elongation often varies systematically within a field, with flutes being end members. Longer streamlined features are most common down-ice from a drumlin field $(9$, 
Table 1. Summary of drumlin-field characteristics. Q is a subjective rating of quality of best drumlins in a field: 1 (wellformed and distinct) to 3 (poorly formed and indistinct). $L$ is sense of longitudinal strain: -, compressive; + , extensive. $T$ is relative transverse strain using $1 / r$ (see text). Material denotes drumlin-forming material and its structure, and Core is described by the same symbols: $B$, sand and gravel-bar deposits in streams; $C l$, clay; Conc, concentric bedding parallel to surface; CT, clayey till; $G$, gravel; GM, ground moraine; IM, ice-marginal deposits; LT, lodgement till; $R K$, rock; $S$, stratified; Sd, sand; SMW, subglacial meltwater deposits; SL, sandy loam; ST, sandy till; T, till. Topo indicates topography over which drumlin-forming ice advanced: APLAT, slightly ascending plateau (ice opposing); CSPLN, coastal plain; DESC, descending slope; DPLAT, slightly descending plateau; ISHGT, isolated height; LLND, lowland; OPPOS, opposing slope; PLAIN, plain; PLAT, plateau

\begin{tabular}{|c|c|c|c|c|c|c|c|c|}
\hline & Field & $Q$ & $L$ & $T$ & Material & Core & Topo & Sources \\
\hline & ALASKA & & & & & & & \\
\hline 1 & $\begin{array}{l}\text { Glacier Bay } \\
\text { ALBERTA }\end{array}$ & 2 & & & & & CSPLN & Goldthwait, 1974 \\
\hline 2 & $\begin{array}{l}\text { Lac La Biche } \\
\text { ANTARCTIC }\end{array}$ & 1 & - & -.05 & $\mathrm{~T}$ & & PLAIN & Jones, 1982 \\
\hline 3 & James Ross Is. & 2 & & & LT & & & Rabassa, 1987 \\
\hline 4 & $\begin{array}{l}\text { BRIT. COLUM. } \\
\text { CHILE }\end{array}$ & 2 & & & & & DESC & Armstrong and Tipper, 1949 \\
\hline 5 & $\begin{array}{l}\text { Patagonia } \\
\text { ENGLAND }\end{array}$ & 2 & - & + & LT & & LLND & Clapperton, 1989 \\
\hline 6 & Cumbria & 2 & & -.22 & ST & RK & LLND & Riley, 1987 \\
\hline 7 & $\begin{array}{l}\text { ESTONIA } \\
\text { FINLAND }\end{array}$ & 2 & - & & $\mathrm{T}$ & RK & LLND & Rõuk and Raukas, 1989 \\
\hline 8 & Keitele & 2 & - & .01 & ST & RK, G,S & PLAT & Gluckert, 1973 \\
\hline 9 & Pieksamaki & 2 & & .01 & ST, S & $\mathrm{RK}, \mathrm{G}, \mathrm{S}$ & PLAT & Gluckert, 1973, 1987 \\
\hline 10 & $\begin{array}{l}\text { N. Finn. Lap. } \\
\text { GERMANY }\end{array}$ & 2 & - & + & $\mathrm{T}$ & & LLND & Heikkinen and Tikkanen, 1979 \\
\hline 11 & Allgau & 2 & - & & $\mathrm{T}, \mathrm{IM}$ & & & De Jong and others, 1982 \\
\hline 12 & Bad Oldesoe & & - & & $\mathrm{T}$ & & & Jauhiainen, 1975 \\
\hline 13 & Brussow & 2 & - & & GM & & PLAIN & Jauhiainen, 1975 \\
\hline 14 & Furstenwerder & 2 & & & GM & & PLAT & Jauniainen, 1975 \\
\hline 15 & Lake Oberucker & 2 & & & GM & & OPPOS & Jauhiainen, 1975 \\
\hline 16 & Lake Lieps & 3 & - & & GM & & LLND & Jauniainen, 1975 \\
\hline 17 & $\begin{array}{l}\text { Rosenow } \\
\text { ICELAND }\end{array}$ & 3 & & & GM & & OPPOS & Jauniainen, 1975 \\
\hline 18 & $\begin{array}{l}\text { South Iceland } \\
\text { IRELAND }\end{array}$ & 3 & & & LT, IM & $\mathrm{B}$ & DESC & ${ }^{\mathrm{a}}$ Kruger and Thomsen, 1984; ${ }^{\mathrm{b}} \mathrm{Kruger}, 1987$ \\
\hline 19 & Ards Peninsula & 2 & - & .01 & $\mathrm{~T}$ & $\mathrm{~T}$ & DESC & “Vernon, 1966; ' ${ }^{\mathrm{a}} \mathrm{Hill}, 1973 ;{ }^{\mathrm{c}}$ Charlesworth, 1939 \\
\hline 20 & Ballina & & & .11 & $\mathrm{~T}$ & & CSPLN & Coudé, 1989 \\
\hline 21 & Castlebar & & - & - & $\mathrm{T}$ & $\mathrm{T}$ & PLAIN & Coudé, 1989 \\
\hline 22 & Clew Bay & 2 & - & .08 & $\mathrm{~T}$ & & DESC & Coudé, 1989 \\
\hline 23 & S. Donegal & 1 & & - & LT, SMW & $\mathrm{T}, \mathrm{RK}$ & DESC & aW. B. Wright, 1912; 'Hanvey, 1989 \\
\hline 24 & Co. Down & 1 & & & $\mathrm{~T}$ & $\mathrm{~T}, \mathrm{RK}$ & LLND & ${ }^{\mathrm{a}}$ Vernon, 1966; ' ${ }^{\mathrm{H}} \mathrm{Hill}, 1973$; ' Charlesworth, 1939 \\
\hline 25 & Lough Neagh & 1 & & & $\mathrm{~T}, \mathrm{~S}$ & & OPPOS & "Charlesworth, 1939; ' ${ }^{\circ}$ ardis and others, 1984 \\
\hline 26 & $\begin{array}{l}\text { Ctrl. Ulster } \\
\text { LITHUANIA }\end{array}$ & & - & .02 & LT, SMW & & OPPOS & Dardis, 1981, 1985 \\
\hline 27 & $\begin{array}{l}\text { Klaipeda } \\
\text { MASS. }\end{array}$ & 3 & - & & $\mathrm{T}$ & & CSPLN & Jauhiainen, 1975 \\
\hline 28 & Boston & 1 & - & .06 & $\mathrm{~T}$ & $\mathrm{~T}, \mathrm{RK}$ & LLND & 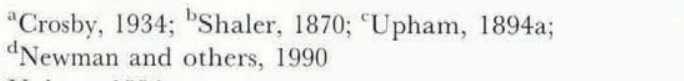 \\
\hline 29 & $\begin{array}{l}\text { Winthrop } \\
\text { MICHIGAN }\end{array}$ & 1 & - & & $\mathrm{T}$ & ST & CSPLN & Upham, 1894a \\
\hline 30 & Alger Co. & 2 & - & & $\mathrm{T}$ & & PLAIN & Bergquist, 1942 \\
\hline 31 & Alpena Co. & & - & & CT & & PLAIN & Bergquist, 1942 \\
\hline 32 & Cheboygan & 1 & - & & & & PLAIN & Bergquist, 1943 \\
\hline 33 & Grand Traverse & 1 & & & & & PLAIN & Bergquist, 1942 \\
\hline 34 & Iron Co. & 1 & - & & & & PLAIN & Bergquist, 1942 \\
\hline 35 & W. Leelanau Co. & & & & & & PLAT & Lontan and Shetron, 1968 \\
\hline 36 & Les Cheneaux & 2 & - & & CT & & PLAT & Bergquist, 1942 \\
\hline 37 & Menominee & 1 & - & & Conc & & PLAIN & Bergquist, 1942 \\
\hline 38 & Mullet Lake & 2 & - & & $\mathrm{T}$ & & PLAIN & Bergquist, 1943 \\
\hline 39 & Northport & 2 & - & & $\mathrm{S}, \mathrm{G}, \mathrm{T}$ & RK & PLAT & Lotan and Shetron, 1968 \\
\hline 40 & Onaway & 2 & - & & $\mathrm{T}$ & & PLAIN & Bergquist, 1943 \\
\hline 41 & Presque Isle Co. & 2 & - & & $\mathrm{T}$ & & PLAIN & $\begin{array}{l}\text { Bergquist, 1942, } 1943 \\
\text { Bergouist. } 1943\end{array}$ \\
\hline $\begin{array}{l}42 \\
43\end{array}$ & & $\begin{array}{l}2 \\
2\end{array}$ & - & & CT & & $\begin{array}{l}\text { PLAIN } \\
\text { PLAIN }\end{array}$ & $\begin{array}{l}\text { Bergquist, } 1943 \\
\text { Bergquist, } 1942\end{array}$ \\
\hline 43 & $\begin{array}{l}\text { Union City } \\
\text { MINNESOTA }\end{array}$ & 2 & & & & & TLAIN & Bergquist, 1942 \\
\hline 44 & Automba & 3 & & & & & OPPOS & Wright, 1973 \\
\hline 45 & Brainerd & 2 & & 0 & & & PLAIN & Wright, 1973 \\
\hline 46 & Pierz & 2 & - & .01 & ST & & DESC & ${ }^{a}$ Wright, 1973; ${ }^{\text {b}}$ Mooers, 1989 \\
\hline 47 & Toimi & & & & & & DESC & Wright and Watts, 1969 \\
\hline 48 & Wadena & 2 & & .02 & $\mathrm{~T}$ & Sd & OPPOS & $\begin{array}{l}\text { aW Wright, 1957, 1962; ' }{ }^{\mathrm{b}} \text { Leverett, 1932; 'Schneider, 1961; } \\
{ }^{\mathrm{d} G o l d s t e i n, 1989}\end{array}$ \\
\hline
\end{tabular}




\begin{tabular}{|c|c|c|c|c|c|c|c|c|}
\hline & Field & $Q$ & $L$ & $T$ & Material & Core & Topo & Sources \\
\hline & NEW HAMP. & & & & & & CSPI N & \\
\hline $\begin{array}{l}49 \\
50\end{array}$ & $\begin{array}{l}\text { in general } \\
\text { Lake Squam }\end{array}$ & 2 & - & & T, CT & $\begin{array}{l}\text { T, S } \\
\text { T }, \mathrm{G}\end{array}$ & $\begin{array}{l}\text { CSPLN } \\
\text { PLAT }\end{array}$ & $\begin{array}{l}\text { Hitchcock, } 1876 \\
\text { Upham. } 1897\end{array}$ \\
\hline 50 & $\begin{array}{l}\text { Lake Squam } \\
\text { NEW YORK }\end{array}$ & & & & $\mathrm{T}$ & $\mathrm{T}, \mathrm{G}$ & & \\
\hline 51 & Ctrl. W. N.Y. & & - & & Conc, $\mathrm{T}$ & & & ${ }^{\text {a} S l a t e r, ~ 1929 ; ~}{ }^{\text {b Fairchild, } 1907}$ \\
\hline 52 & Chautauqua & 1 & - & & & RK & PLAT & ${ }^{\text {a } M u l l e r, ~ 1963 ; ~ ' ~ F a i r c h i l d, ~ 1907 ; ~ ' ~ M i l l e r, ~} 1972$ \\
\hline 53 & W. Finger Lakes & & - & & $\mathrm{T}$ & & LLND & Fairchild, 1907 \\
\hline 54 & Niagara-Geness & 3 & - & & $\mathrm{T}$ & & PLAT & Fairchild, 1907 \\
\hline 55 & Palmyra & 1 & - & & $\mathrm{T}$ & RK & LLND & Fairchild, 1907 \\
\hline 56 & $\begin{array}{l}\text { Sodus Bay } \\
\text { N. DAKOTA }\end{array}$ & 2 & - & & Conc, $\mathrm{T}$ & & OPPOS & Fairchild, 1907 \\
\hline 57 & Warwick-Tokio & 3 & - & .04 & $\mathrm{~T}$ & & LLND & 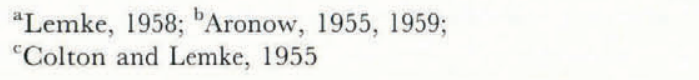 \\
\hline 58 & $\begin{array}{l}\text { N.W. TERR. } \\
\text { Barren Grounds }\end{array}$ & 2 & & 0 & CT & & & Dean, 1953 \\
\hline $\begin{array}{l}59 \\
60\end{array}$ & $\begin{array}{l}\text { P. of Wales Is. } \\
\text { Chezzetcook }\end{array}$ & 2 & - & -.07 & $\mathrm{~T}$ & & & 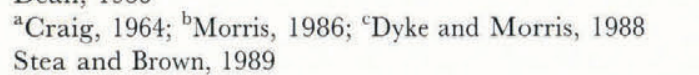 \\
\hline 61 & Halifax & 1 & - & .02 & $\mathrm{~T}$ & $\mathrm{~T}, \mathrm{LT}$ & DESC & Goldthwait, 1924 \\
\hline 62 & Liscomb & & & & & & & Stea and Brown, 1989 \\
\hline 63 & Lunenburg & & & & & & & Stea and Brown, 1989 \\
\hline 64 & $\begin{array}{l}\text { Yarmouth } \\
\text { ONTARIO }\end{array}$ & 2 & & .02 & $\mathrm{G}, \mathrm{T}$ & & CSPLN & ${ }^{\mathrm{a}}$ Gravenor, 1974; ${ }^{\mathrm{b}}$ Stea and Brown, 1989 \\
\hline 65 & Arran & 2 & - & + & $\mathrm{T}$ & $\mathrm{G}, \mathrm{Sd}, \mathrm{T}$ & PLAT & ${ }^{\mathrm{a}}$ Chapman and Putnam, 1966; ${ }^{\mathrm{b}}$ Harry and Trenhaile, 1987 \\
\hline 66 & Big Head Valley & 1 & & & & & LLND & ${ }^{\mathrm{a}}$ Chapman and Putnam, 1966; ${ }^{\mathrm{b}}$ Harry and Trenhaile, 1987 \\
\hline 67 & Caledonia & & - & & & & LLND & ${ }^{\mathrm{a}}$ Chapman and Putnam, 1966; ${ }^{\mathrm{b}}$ Harry and Trenhaile, 1987 \\
\hline 68 & N. Gower & 2 & - & & SL & & OPPOS & ${ }^{\mathrm{a} C h a p m a n}$ and Putnam, 1966; ${ }^{\mathrm{b}}$ Harry and Trenhaile, 1987 \\
\hline 69 & Guelph & 2 & - & & ST & $\mathrm{T}$ & OPPOS & ${ }^{\mathrm{a}}$ Chapman and Putnam, 1966; ${ }^{\mathrm{b}}$ Harris, $1967 ;{ }^{\mathrm{c}}$ Karrow, 1981 \\
\hline 70 & Manitoulin Is. & 2 & & & $\mathrm{~T}$ & & DPLAT & Chapman and Putnam, 1966 \\
\hline 71 & S. Ottawa & & - & & ST & & & Karrow, 1981 \\
\hline 72 & Peterborough & 2 & - & & ST & $\mathrm{G}, \mathrm{Sd}, \mathrm{Cl}$ & LLND & ${ }^{\mathrm{a}}$ Karrow, 1981; ${ }^{\mathrm{b}}$ Crozier, 1975; 'Sharpe, 1987 \\
\hline 73 & Simcoe & 1 & - & & & & LLND & Chapman and Putnam, 1966 \\
\hline 74 & Teeswater & 1 & - & & ST & & PLAIN & Karrow, 1981 \\
\hline 75 & $\begin{array}{l}\text { Woodstock } \\
\text { POLAND }\end{array}$ & & - & .02 & ST & $\mathrm{T}, \mathrm{S}$ & DESC & 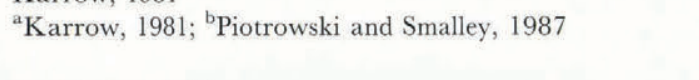 \\
\hline 76 & Dobropole & 3 & - & & GM & & & Jauhiainen, 1975 \\
\hline 77 & Dzwnowo & 2 & - & & $\mathrm{T}$ & & DESC & Jauhiainen, 1975 \\
\hline 78 & Kornik & 2 & - & & $\mathrm{T}$ & & & Jauhiainen, 1975 \\
\hline 79 & Smiegiel & 2 & - & & $\mathrm{T}$ & & & Jauhiainen, 1975 \\
\hline 80 & $\begin{array}{l}\text { Stargaard } \\
\text { QUEBEC }\end{array}$ & 2 & - & & $\mathrm{T}$ & & LLND & a Jauhiainen, 1975; ' Karczewski, 1987 \\
\hline 81 & $\begin{array}{l}\text { Ungava Penin. } \\
\text { SASKATCH. }\end{array}$ & 2 & & & LT & & PLAT & ${ }^{\mathrm{a}}$ Gray and Lauriol, 1985; ${ }^{\mathrm{b}}$ Bouchard, 1989 \\
\hline 82 & Dollard & 1 & - & & $\mathrm{S}$ & & LLND & Kaupsch, 1955 \\
\hline 83 & Livingstone Lake & 2 & - & .01 & $\mathrm{~S}$ & & PLAT & Shaw and Kvill, 1984 \\
\hline & subset of L.L. & 2 & - & & & $\mathrm{S}$ & PLAT & \\
\hline & subset of L.L. & 3 & - & & & $\mathrm{S}$ & PLAT & \\
\hline 84 & $\begin{array}{l}\text { SCOTLAND } \\
\text { SWEDEN }\end{array}$ & & & & & & & Charlesworth, 1939 \\
\hline 85 & Boras & 2 & & & $\mathrm{~T}$ & RK & PLAT & Gillberg, 1976 \\
\hline 86 & Emmaboda & 2 & - & & $\mathrm{ST}$ & RK & PLAT & Gillberg, 1976 \\
\hline 87 & Falbygden & 1 & - & & & RK & ISHGT & Gillberg, 1976 \\
\hline 88 & Falkenberg & 3 & - & & & & CSPLN & Gillberg, 1976 \\
\hline 89 & Kinnekulle & 2 & - & 0 & & & ISHGT & Gillberg, 1976 \\
\hline 90 & Narke & 3 & - & 0 & & G & LLND & Gillberg, 1976 \\
\hline 91 & Sommen Solgen & 2 & - & .01 & & RK & APLAT & Gillberg, 1976 \\
\hline 92 & $\begin{array}{l}\text { Varend } \\
\text { WASHINGTON }\end{array}$ & 2 & - & .01 & & RK & DPLAT & Gillberg, 1976 \\
\hline 93 & $\begin{array}{l}\text { Puget Lowland } \\
\text { WISCONSIN }\end{array}$ & & - & & & & DESC & Waitt and Thorson, 1983 \\
\hline 94 & Madison & 1 & - & .03 & $\mathrm{~T}$ & $\mathrm{Sd}, \mathrm{G}, \mathrm{S}$ & OPPOS & 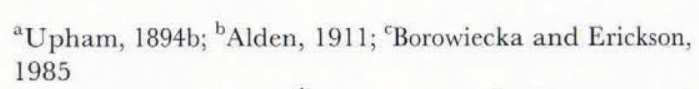 \\
\hline 95 & Waukesha Co. & 2 & & .02 & $\mathrm{~T}$ & G, RK & & $\begin{array}{l}\text { a Alden, 1905, 1911; }{ }^{b} \text { Lasca, 1970; }{ }^{c} \text { Whittecar and } \\
\text { Mickelson, 1979 }\end{array}$ \\
\hline
\end{tabular}

$\left.52,54,55,74,80^{\mathrm{b}}\right)$, but were also found up-ice from drumlins $(48,57)$ and in both locations $(2)$.

Consistent with the pattern of flutes forming nearest the ice margin is the observation that, during a glacier retreat, flutes tend to form later than drumlins and therefore under thinner ice $(11,82-84)$.

\section{Topography}

Regional large-scale topography, because of its effect on ice dynamics, should be a significant variable in drumlin formation. However, our data suggest that this is not the case. Topographic descriptions were taken from the 
literature where available, or deduced from topographic maps. Drumlins are almost equally common on plains, on highlands, such as plateaus and isolated flat hilltops, and in confined lowlands (Table 1). Slopes do not appear to be particularly important unless they are exceptionally steep.

\section{Patterns of drumlin spacing and spatial organization}

Distinct spatial patterns are observed in drumlin fields, and variations in drumlin density are common. One frequently mentioned spatial pattern consists of alternating concentric bands of high and low drumlin density that are perpendicular to the ice-flow direction $(10,25,28,52$, 85, 94, 95). Typically the drumlin shapes and sizes are similar within a band (Fairchild, 1905; Muller, 1963; Shaw and Kvill, 1984). The spacing of the bands may decrease up-glacier (25). Each band may represent a separate period of drumlin formation associated with a still stand of the ice margin during a general retreat $\left(46^{\mathrm{b}}\right.$, $\left.94^{\mathrm{b}}\right)$.

Other fields or areas of fields have a radial banding parallel to the ice-flow direction $(4,83,85,95)$. The outer parts of one field $\left(94^{\mathrm{c}}\right)$ are characterized by radial bands, but transverse bands are present in the central part.

Often mentioned in theories of drumlin formation is the "en echelon" pattern of drumlin spacing (4, 5, 8, 9, $18,19,24)$. This is not the most commonly seen pattern, and no field is entirely "en echelon". Other patterns of drumlin grouping are parallel (side by side) $(8,9,18,85$ $87,90-92)$, in succession down-ice $(9,85,87,91,92)$ and overlapping or fused $(4,9,11,55,87,91,92)$.

\section{Drumlin-forming material}

Most drumlins comprise a composite of materials of local derivation. These materials are typically glacial, but sometimes even weak bedrock may be molded into drumlin forms (52). In general, tills in drumlins tend to be rich in sand and gravel (Karrow, 1981). The suggestion that drumlins are composed only of clay-rich material (Fairchild, 1907) has been disproved, not only in general (Karrow, 1981), but also with respect to the specific area (52) studied by Fairchild (Muller, 1963). Three recent regional investigations note a correspondence of drumlin fields with an up-ice source of easily erodible, fine-grained, sedimentary rock (Aylsworth and Shilts, 1989; Bouchard, 1989; Coudé, 1989).

Almost half of the drumlins having exposed interiors have distinct cores. The core may be almost anything: an older, denser till; stratified sand and gravel, or gravel and till; stratified clay; or solid rock. These observations demonstrate that some drumlins are partly erosional in origin. However, others clearly have a depositional component. Any general theory of drumlin formation must accommodate both possibilities.

In some drumlinized areas, small topographic perturbations that might have formed cores did not become drumlins (Fairchild, 1907; Aronow, 1959; Gluckert, 1973; Gillberg, 1976). Thus the presence of a perturbation alone, even within a drumlin field, appears not to be sufficient to cause drumlin formation.

\section{Substrate material}

The substrate is defined as the bedrock or sediment on which drumlins were deposited. Surrounding material that was deposited at or after the time of drumlin formation is not considered to be part of the substrate, but material in a drumlin core that is laterally continuous is considered to be part of the substrate.

Unconsolidated sediments make up $34 \%$ of the substrates, $18 \%$ being till and $16 \%$ being stratified sediments, typically of outwash origin. The remaining $66 \%$ are rock. One-third of the rock substrates are shales and slates, one-third crystalline rocks, and one-quarter carbonates, with sandstones, conglomerates and basalts making up the remainder. In short, drumlin development is not obviously linked to lithology of the substrate.

In many fields the density of drumlins decreases with decreasing depth of glacial sediment $(40,41,52,58,64$, $69,72)$. In addition, well-formed drumlins tend to occur on thicker sediment, while imperfect, poorly shaped drumlins of lower relief occur in areas of thin sediment $\left(40,72^{\mathrm{a}}, 81^{\mathrm{b}}\right)$. In other fields, however, the amount of loose debris overlying the bedrock does not appear to be an important variable $\left(68,72^{\mathrm{b}}, 85-92\right)$.

\section{Time of formation}

While it is often possible to determine the relative ages of various features within a drumlin field, the lack of absolute ages for the original deposition of drumlinforming material and the difficulty of determining whether the drumlin material is of the same age as the drumlin formation make interpretations of timing difficult. In addition, drumlins in different parts of a field may have formed at different times.

The most likely time for drumlins to form (or to form and then be preserved) appears to be during the final stages of advance and the early stages of retreat of the ice mass. Where ice-movement directions are inferred to have been different during advance and retreat, drumlins are aligned with the retreat direction (Fairchild, 1907; Lundqvist, 1970).

Drumlin fields in North America are no older than late-Wisconsinan, and all preserved drumlin fields of significant size appear to have formed during this time period in the late Pleistocene. If drumlins formed during earlier glacial times, they probably were eroded or masked by subsequent glaciations. Only three fields, consisting of a few very small drumlins, are described from the Holocene $(1,3,18)$.

\section{Basal conditions}

Drumlins apparently form in a restricted zone somewhat up-glacier from, and separated from, the associated ice margin. Normally there is a drumlin-free zone immediately up-glacier from the moraine. Drumlin belts occur $10-80 \mathrm{~km}\left(95^{\mathrm{c}}\right), 2-16 \mathrm{~km}\left(57^{\mathrm{c}}\right), 5-50 \mathrm{~km}(96), 2-10 \mathrm{~km}$ (Dardis and others, 1984), 20-30 km (48), 15-20 km (5), and at least $25 \mathrm{~km}$ (46) behind the associated moraine. The drumlin-free zone may be due to some minimum ice thickness being required for drumlin formation. The Warwick-Tokio field (57) may be an exception to this 
rule if the drumlins and moraine are contemporaneous.

Temperature modeling suggests that steady-state basal temperatures in such areas were probably at the melting point (Moran and others, 1980). This follows from the fact that temperatures in polar glaciers increase rapidly with depth in the ablation zone (e.g. Hooke, 1977). Ice can, of course, advance over a zone of permafrost, leading to non-steady-state, sub-freezing, basal temperatures that can persist for a period of some decades or perhaps even centuries. But the observation (previous sub-section) that drumlins seem to form during late phases of an ice advance suggests that thermal conditions may have had time to reach the steady state.

Drumlins are found as far south as $43^{\circ} \mathrm{N}$ in North America and $46^{\circ} \mathrm{N}$ in Europe, and as far north as $53^{\circ} \mathrm{S}$ in the Southern Hemisphere (Fig. 1). Although thawed-bed conditions existed beneath much of the ice sheet, these latitudes suggest that frozen margins may have been present. Such frozen margins can be up to $2-3 \mathrm{~km}$ wide (Moran and others, 1980).

Glacial-thrust features are additional evidence of frozen margins (Moran and others, 1980). These features apparently form when the bed becomes frozen to the glacier sole near the margin, while melting conditions exist somewhat farther up-glacier. In North America, late-Wisconsinan thrust features are common in North Dakota (Moran and others, 1980), western Canada from southern Saskatchewan to east-central Alberta (Kupsch, 1961) central to northern Minnesota (Mooers, 1990) and Ontario (Crozier, 1975; Gray and Lauriol, 1985), all of which are major drumlin areas.

Secondly, in the ablation zones of glaciers and ice sheets with frozen margins there is generally a significant concentration of surficial debris (Goldthwait and others, 1951; Boulton, 1968, 1971; Moran, 1971; Hooke, 1973; Menzies, 1979). Hummocky moraine and dead-ice topography form as a result of this debris. Such topography is characteristic of moraines down-ice from drumlin fields.

Thirdly, paleoclimatic reconstructions provide an approach to assessing the condition of the ice margin, since a mean annual temperature of less than $-5^{\circ} \mathrm{C}$ but not much lower than $-10^{\circ} \mathrm{C}$ is probably needed to form a frozen margin of significant $(2 \mathrm{~km})$ width, (Moran and others, 1980). For example, a yearly average temperature of below $-2^{\circ} \mathrm{C}$ is needed for permafrost, and as a rule permafrost is present everywhere north of the $-6^{\circ}$ to $-8^{\circ} \mathrm{C}$ isotherms (Williams, 1975). In areas of drumlin formation in Europe, the mean annual temperature was appreciably below $-2{ }^{\circ} \mathrm{C}$ and possibly as cold as $-12{ }^{\circ} \mathrm{C}$ (Frenzel, 1973). In the U.S.A., the upper Midwest (North Dakota; Minnesota) probably had a mean annual temperature between $-7^{\circ}$ and $-10^{\circ} \mathrm{C}$ with low accumulation, favoring permafrost development (Barry, 1983). Thus permafrost is likely to have bordered the ice sheet in areas where drumlins formed. Continuous permafrost existed in Wisconsin from 25000 to $13000 \mathrm{BP}$ (Clayton and Attig, 1989).

A frozen margin in and of itself cannot be a requirement for drumlin formation, however, because many lobes that formed drumlins were floating at the terminus $(1,19,22-26,28,32,36,38,60-65,70,81,84)$. One key characteristic that marine-based ice lobes probably shared with those that had frozen margins is high pore-water pressure. In the case of the marine-based lobes, this would have been provided simply by the height of the water surface against a calving face.

\section{Ice thickness and basal shear stress}

Since drumlins formed relatively near ice margins, the ice under which they developed cannot have been very thick. The lobate shape of many ice margins associated with drumlin fields also indicates that the ice was thin and controlled by topography. Precise estimates of ice thickness at the time of drumlin formation are few.

In the case of the Holocene drumlins of southern Iceland (18), the ice was $100-150 \mathrm{~m}$ thick over the drumlin field during the maximum historical extension. Drumlins are absent from the terminal $500 \mathrm{~m}$ of the glacier forefield where the maximum ice thickness was less than $100 \mathrm{~m}$ (Kruger and Thomsen, 1984).

Nunataks provide a record of ice thicknesses over drumlins. In one case (82) a maximum thickness of $400 \mathrm{~m}$ was found, and in another $\left(94^{\mathrm{b}}\right)$ the thickness ranged between 140 and $440 \mathrm{~m}$. A reconstruction of the Puget lobe (93) yielded a maximum ice thickness of $200-300 \mathrm{~m}$ at the terminus and $1100-1200 \mathrm{~m}$ at $250 \mathrm{~km}$ from the margin. Drumlins formed throughout this zone.

Assuming a parabolic profile and constant basal shear stress, the shear stresses in the above examples are 0.15 bar (82), $0.11-0.35$ bar (94) and $0.14-0.22$ bar (93). In the last case, the calculated shear stress depends on whether the drumlins formed all at one time or successively as the ice retreated. These basal shear stresses suggest that ice flow may have been relatively sluggish at the time of drumlin formation. However, it is also possible that the low shear stresses implied by thin ice reflect the weakness of the bed over which the ice was moving.

\section{Sense of strain in the glacier}

Longitudinal compression is characteristic of ablation areas of glaciers. On present-day ice caps and ice sheets the ablation area comprises approximately the outer $10 \%$ of the flowline. Most drumlin fields are located sufficiently near a contemporaneous ice margin to ensure that they formed beneath the ablation area.

Although drumlin patterns are not always simple and symmetric (Slater, 1929; Gillberg, 1976), the sense of transverse strain can usually be determined by the pattern of drumlins within a field. Fan-shaped fields result from transverse extension and funnel-shaped fields from transverse compression.

In a cylindrical flow field, the circumferential (or transverse) strain rate, $\varepsilon_{\theta}$ is $u / r$ (Nye, 1953) where $u$ is the ice velocity in the down-glacier direction and $r$ is the distance from the axis of the cylinder. However, the velocity of the ice under which the drumlins formed is unknown, and $r$ varies. Thus, to obtain a more quantitative measure of relative transverse strain rates, we chose a point where two typical drumlins were $1 \mathrm{~km}$ apart, drew radii parallel to the axes of these drumlins and measured the distance from either of the drumlins to the point of intersection of the radii. Lines converging in 

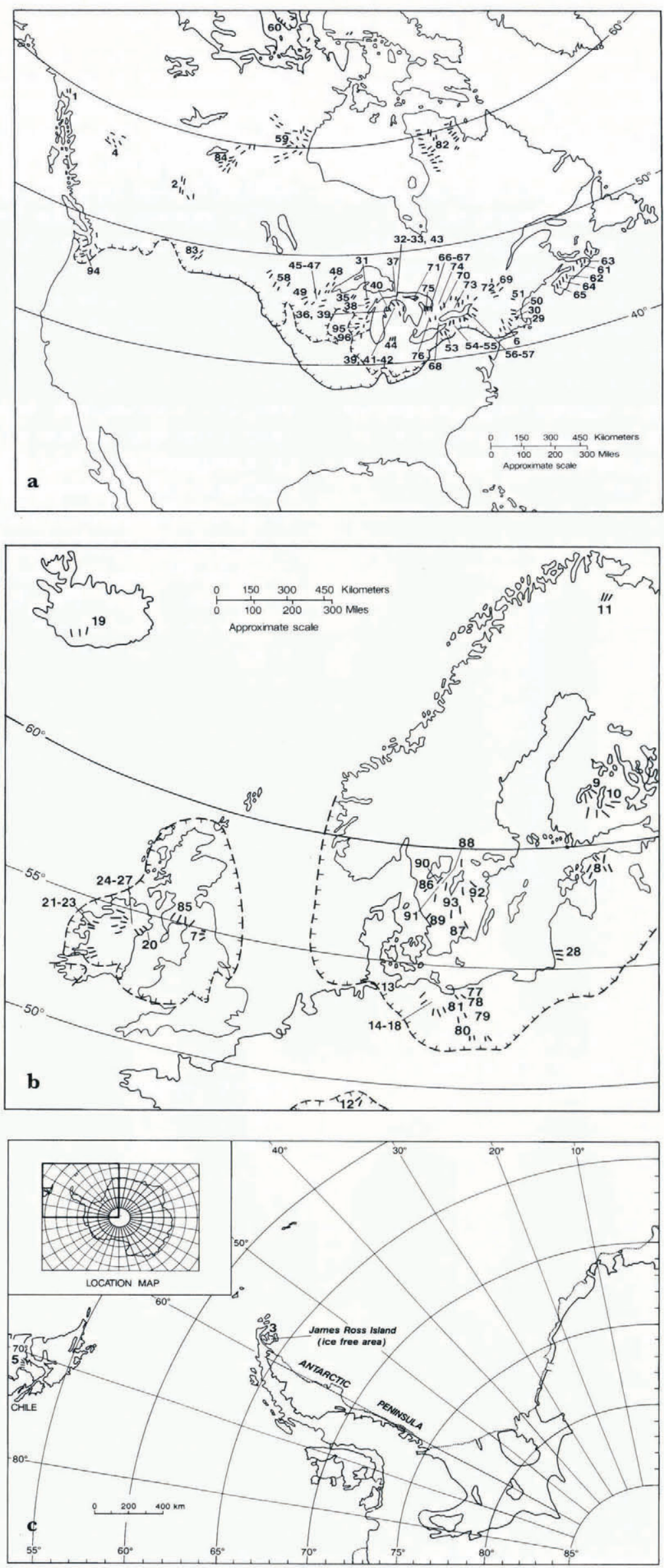

Fig. 1. Locations of the drumlin fields considered in this study in (a) North America, (b) Europe, and (c) Antarctica and Chile. Numbers keyed to Table 1. "' General trend of drumlins. $\perp \perp \perp$ Limit of late-Wisconsinan or correlative ice advance. $\perp \amalg \amalg \perp$ Maximum Pleistocene ice advance in North America. 
an up-ice direction define a positive value for $r$, and diverging lines define a negative value. The reciprocal of this distance, $1 / r$, is then equal to $\varepsilon_{\theta / u}$ for that particular location, and to the extent that $u$ does not vary excessively among the various drumlin-forming situations, the ratio $\varepsilon_{\theta / u}$ is a measure of the relative value of $\varepsilon_{\theta}$. This measurement was made wherever fields were adequately mapped and drumlin orientations sufficiently consistent to make a meaningful measurement.

In the drumlin fields studied, $1 / r$ ranges from -0.22 to 0.08 , with more than half the values falling between 0.01 and 0.02 (Table 1; Fig. 2). Thus, the majority of drumlin fields apparently formed under conditions of transverse extension. This may be simply because they are located in the ablation area, where transverse extension is common, but the cluster of $1 / r$ values between 0 and 0.02 may be significant. Only three fields considered here $(2,6,59)$ have negative values. In one of these (59) the ice involved may have been an ice stream.

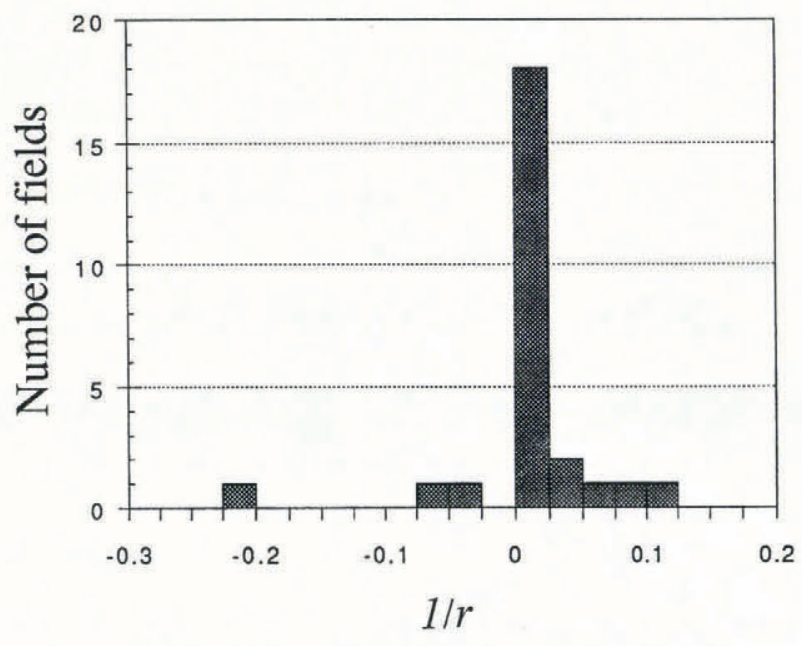

Fig. 2. Histogram of $1 / r$ values for the drumlin fields measured. The ratio $1 / r$ is a measure of relative transverse strain rate. Positive values indicate transverse extension. See text for explanation.

\section{The role of water}

Evidence for the presence of subglacial water at the time of drumlin formation is theoretical and/or indirect. As noted earlier, temperature models suggest that the beds of land-based lobes, in the region of drumlin formation somewhat up-glacier from the margins, were probably at the pressure-melting temperature. In the case of marinebased lobes, subglacial temperatures were certainly at the pressure-melting point.

In both cases, pore-water pressures were probably high. In the case of land-based glaciers, as noted, drumlin areas border margins that were probably in the permafrost zone. Frozen margins would have blocked the release of meltwater, thus increasing subglacial water pressures. Moran and others (1980) attribute the formation of glacial-thrust terrane, often found down-glacier from drumlin fields, to high pore-water pressures. Porewater pressures were probably also high in the case of marine-based margins, particularly if the water was deep.
The thin-ice profiles reconstructed above imply low basal shear stresses. A weak bed, resulting from high porewater pressures would be consistent with these observations. There are a few documented cases of drumlins containing deformation structures such as diapirs or dikes (e.g. 95). Such features can be created by the flow of saturated sediment as a result of weakening of the sediment by high pore-water pressure.

The presence of fluvial sediment beneath drumlins does not necessarily mean that the fluvial deposition was contemporaneous with drumlinization. Stratified deposits lapping onto a drumlin in its lee (Chapman and Putnam, 1966; Dardis and others, 1984) require the drumlin for their accumulation, but there is no evidence that the fluvial activity and drumlin formation were related. However, concentrically bedded, fluvially deposited, upper layers that conform to the drumlin profile, as in the Livingstone Lake field (83), suggest that fluvial accumulation may have been an integral part of the later phases of the formation of some drumlins. Likewise, the common association of eskers $(8,9,24,26,29,30,37,46$, $72,81-83,88)$ and, less commonly, tunnel valleys $(46,83$, 94; Grube, 1983), with drumlins is not conclusive evidence for the presence of water at the time of drumlin formation, because some drumlins are known to pre-date these features. However, eskers and tunnel valleys are indicative of subglacial drainage shortly after drumlin formation. Although these observations do not relate conclusively to the subglacial hydrology during drumlin formation, they suggest that water was present soon after formation.

In summary, high pore-water pressures likely existed in all of the drumlin fields studied, because at least one of the following is true: (1) a frozen toe was probably present; (2) the glacier terminated in water; (3) subglacial drainage followed drumlin formation; (4) fluvial deposits are an integral part of the drumlin form; or (5) the till is deformed.

\section{CONGLUSIONS}

Parameters studied that were significantly variable were (1) regional topography, (2) material in drumlins, (3) substrate lithology, and (4) substrate thickness. These, therefore, are not central to drumlin formation.

Shared characteristics are linked to ice physics. Drumlins were formed within the ablation area relatively near ice margins. As a result, the longitudinal strain rate was normally compressive and the transverse strain rate extending. The ice must have been relatively thin. The drumlin-free zone between the moraine and the drumlin field suggests, however, that there is a limit to how thin the ice can be and still form drumlins. This drumlin-free zone varies from 2 to $25 \mathrm{~km}$ in width.

In many drumlin fields a frozen toe was probably present. Evidence for this includes paleoclimatic reconstructions, ice-thrust features and areas of stagnation moraine. Such a frozen toe would be likely to cause high pore-water pressures in the area of drumlin formation. Frozen toes could not have been present where ice sheets terminated in water, but the presence of an appreciable depth of water at the terminus would also have led to high 
pore-water pressures farther up-glacier. No drumlin fields were found in areas where elevated pore-water pressures would have been unlikely.

Within fields, two common patterns of drumlin spacing can be distinguished: transverse and radial banding. Transverse banding is the more common and may be a result of time-transgressive formation of drumlins during retreat of an ice margin. One drumlin form typically dominates an area within a field, and the change to another form is gradual. Drumlins normally become elongated down-ice.

\section{ACKNOWLEDGEMENTS}

In the evolution of our ideas on drumlins, we have benefited from discussions with D. Mickelson, H. Mooers, J. Shaw and R. Shreve. The critical comments of D. MacAyeal significantly improved the presentation. This research was supported in part by the University of Minnesota Graduate School.

\section{REFERENGES}

Alden, W. C. 1905. Drumlins of south-eastern Wisconsin. U.S. Geol. Surv. Bull. 273, 946.

Alden, W.C. 1911. Radiation of glacial flow as a factor in drumlin formation. Geol. Soc. Am. Bull., 22, 733-734.

Armstrong, J.E. and H.W. Tipper. 1949. Glaciation in north-central British Columbia. Am. J. Sci., 246, 283-310.

Aronow, S. 1955. Problems in late Pleistocene and recent history of the Devils Lake region, North Dakota. (Ph.D. dissertation, University of Wisconsin.)

Aronow, S. 1959. Drumlins and related streamline features in the Warwick-Tokio area, North Dakota. Am. J. Sci., 257, 191-203.

Aylsworth, J. M. and W. W. Shilts. 1989. Bedforms of the Keewatin ice sheet, Canada. Sediment. Geol., 62(3-4), 407-428.

Barry, R.G. 1983. Late-Pleistocene climatology. In Wright, H. E., Jr and S. C. Porter, eds. Late Quaternary environments of the United States. Vol. 1. Minneapolis, MN, University of Minnesota Press, 390-407.

Bergquist, S. G. 1942. The distribution of drumlins in Michigan. Papers of the Michigan Academy of Science, Arts, and Letters, 27, 451-464.

Bergquist, S. G. 1943. New drumlin areas in Cheboygan and Presque Isle counties, Michigan. Papers of the Michigan Academy of Science, Arts, and Letters, 28, $481-485$.

Borowiecka, B.Z. and R:H. Erickson. 1985. Wisconsin drumlin field and its origin. Z. Geomorphol., N.F., $29(4), 417-438$

Bouchard, M.A. 1989. Subglacial landforms and deposits in central and northern Quebec, Canada, with emphasis on rogen moraines. Sediment. Geol., 62(3-4), 293-308.

Boulton, G.S. 1968. Flow tills and related deposits ón some Vestspitsbergen glaciers. f. Glaciol., 7(51), 391-412.

Boulton, G.S. 1971. Till genesis and fabric in Svalbard, Spitsbergen. In Goldthwait, R.P., ed. Till: a symposium. Columbus, $\mathrm{OH}$, Ohio State University Press, 41-72.

Chapman, L. J. and D. F. Putnam. 1966. The physiography of southern Ontario. Ontario Geological Survey. Special Volume 2.

Charlesworth, J.K. 1939. Some observations on the glaciation of northeast Ireland. Proc. R. Ir. Acad., Sect. B, 45(11), 361-371.

Clapperton, C. M. 1989. Asymmetrical drumlins in Patagonia, Chile. Sediment. Geol., 62(3-4), 387-398.

Clayton, L. and J. W. Attig. 1989. Glacial Lake Wisconsin. Geol. Soc. Am. Mem. 173.

Colton, R. B. and R. W. Lemke. 1955. Drumlins in North Dakota. [Abstract.] Geol. Soc. Am. Bull., 66, 1673

Coudé, A. 1989. Comparative study of three drumlin fields in western Ireland: geomorphological data and genetic implications. Sediment. Geol., 62(3-4), 321-335.

Craig, B. G. 1964. Surficial geology of Boothia Peninsula and Somerset, King William and Prince of Wales Islands, District of Franklin. Geol. Surv. Can. Pap. 63-44.
Crosby, I. B. 1934. Evidence from drumlins concerning the glacial history of the Boston basin. Geol. Soc. Am. Bull., 45, 135-158.

Crozier, M.J. 1975. On the origin of the Peterborough drumlin field: testing the dilatancy theory. Can. Geogr., 19(3), 181-195.

Dardis, G. F. 1981. "Stagnant-ice" topography and its relation to drumlin genesis, with reference to south-central Ulster. (Abstract only.) Ann. Glaciol., 2, 183.

Dardis, G. F. 1985. Till facies associations in drumlins and some implications for their mode of formation. Geogr. Ann., 67A (1-2), 13-22.

Dardis, G. F., A. M. McCabe and W. I. Mitchell. 1984. Characteristics and origins of lee-side stratification sequences in Late Pleistocene drumlins, northern Ireland. Earth Surface Processes and Landforms, 9(5), $409-424$.

Dean, W. G. 1953. The drumlinoid landforms of the "Barren Grounds", N.W.T. Can. Geogr., 3, 19-30.

De Jong, M. G. G., M. Rappol and J. Rupke. 1982. Sedimentology and geomorphology of drumlins in western Allgäu, south Germany. Boreas, $11(1), 37-45$.

Dyke, A. S. and T.F. Morris. 1988. Drumlin fields, dispersal trains, and ice streams in Arctic Canada. Can. Geogr., 32(1), 86-90.

Fairchild, H. L. 1905. New York drumlins. [Abstract.] Geol. Soc. Am. Bull., 16, 576

Fairchild, H. L. 1907. Drumlins of central western New York. N.r. State Mus. Bull. 111, 391-443.

Frenzel, B. 1973. Climatic fluctuations of the ice age. Cleveland, $\mathrm{OH}$, and London, Case Western Reserve University Press.

Gillberg, G. 1976. Drumlins in southern Sweden. Bull. Geol. Inst. Univ. Upps., 6, 125-189.

Glückert, G. 1973. Two large drumlin fields in central Finland. Fennia, 120.

Glückert, G. 1987. The drumlins of central Finland. In Menzies, J. and J. Rose, eds. Drumlin Symposium. Rotterdam, Balkema, 291-294.

Goldstein, B. 1989. Lithology, sedimentology, and genesis of the Wadena drumlin field, Minnesota, U.S.A. Sediment. Geol., 62(3-4), 241-277.

Goldthwait, J. W. 1924. Physiography of Nova Scotia. Geol. Surv. Can. Mem. 140.

Goldthwait, J. W., L. Goldthwait and R. P. Goldthwait. 1951. The geology of New Hampshire. Part 1. Surficial geology. Concord, NH, New Hampshire State Planning and Development Commission.

Goldthwait, R. P. 1974. Rates of formation of glacial features in Glacier Bay, Alaska. In Coates, D. R., ed. Glacial geomorphology. Binghamton, NY, State University of New York, 163-185.

Gravenor, C. P. 1974. The Yarmouth drumlin field, Nova Scotia. I. Glaciol., $13(67), 45-54$.

Gray, J. T. and B. Lauriol. 1985. Dynamics of the Late Wisconsin ice sheet in the Ungava Peninsula interpreted from geomorphological evidence. Arct. Alp. Res., 17(3), 289-310.

Grube, F. 1983. Tunnel valleys. In Ehlers, J., ed. Glacial deposits in northwest Europe. Rotterdam, Balkema, 257-258.

Hanvey, P. M. 1989. Stratified flow deposits in a Late Pleistocene drumlin in northwest Ireland. Sediment. Geol., 62(3 4), 211-221.

Harris, S. A. 1967. Origin of part of the Guelph drumlin field and the Galt and Paris moraines, Ontario - a reinterpretation. Can. Geogr., 11(1), 16-34.

Harry, D. G. and A.S. Trenhaile. 1987. The morphology of the Arran drumlin field, southern Ontario, Canada. In Menzies, J. and J. Rose, eds. Drumlin Symposium. Rotterdam, Balkema, 161-173.

Heikkinen, O. and M. Tikkanen. 1979. Glacial flutings in northern Finnish Lapland. Fennia, 157 (1), 1-12.

Hill, A. R. 1973. The distribution of drumlins in County Down, Ireland. Ann. Assoc. Am. Geogr., 63 (2), 226-240.

Hitchcock, C. H. 1876. Lenticular hills of glacial drift. Proceedings of the Boston Society of Natural History, 19, 63-67.

Hooke, R. LeB. 1973. Structure and flow in the margin of the Barnes Ice Cap, N.W.T., Canada. 7. Glaciol., 12(66), 423-438.

Hooke, R. LeB. 1977. Basal temperatures in polar ice sheets: a qualitative review. Quat. Res., 7(1), 1-13.

Jauhiainen, E. 1975. Morphometric analysis of drumlin fields in northern Central Europe. Boreas, 4(4), 219-230.

Jones, N. 1982. The formation of glacial flutings in east-central Alberta. In Davidson-Arnott, R., W. Nickling and B. O. Fahey, eds. Research in glacial, glacio-fluvial, and glacio-lacustrine systems. Proceedings of the 6th Guelph Symposium on Geomorphology, 1980. Norwich, Geo Books, 49-70.

Karczewski, A. 1987. Lithofacies variability of a drumlin in Pomerania, Poland. In Menzies, J. and J. Rose, eds. Drumlin Symposium. Rotterdam, Balkema, 177-183.

Karrow, P. F. 1981. Till texture in drumlins. F. Glaciol., 27(97), 497-502.

Krüger, J. 1987. Relationship of drumlin shape and distribution to drumlin stratigraphy and glacial history, Mýrdalsjökull, Iceland. In 
Menzies, J. and J. Rose, eds. Drumlin Symposium. Rotterdam, Balkema, 257-266.

Krüger, J. and H.H. Thomsen. 1984. Morphology, stratigraphy, and genesis of small drumlins in front of the glacier Mýrdalsjökull, south Iceland. 7. Glaciol., 30(104), 94-105.

Kupsch, W. O. 1955. Drumlins with jointed boulders near Dollard, Saskatchewan. Geol. Soc. Am. Bull., 66(3), 327-338.

Kupsch, W. O. 1961. Ice-thrust ridges in western Canada. J. Geol., 70 $(5), 582-594$.

Lasca, N. P. 1970. The drumlin field of southeastern Wisconsin. Wis. Geol. Nat. Hist. Surv. Inf. Circ. 13, part E, 1-13.

Lemke, R. W. 1958. Narrow linear drumlins near Velva, North Dakota. Am. J. Sci., 256, 270-283.

Leverett, F. 1932. Quaternary geology of Minnesota and parts of adjacent states. U.S. Geol. Surv. Prof. Pap. 161.

Lotan, J.E. and S.G. Shetron. 1968. Characteristics of drumlins in Leelanau County, Michigan. Michigan Academy of Science, Arts, and Letters, 53, 78-79.

Lundqvist, J. 1970. Studies of drumlin tracts in central Sweden. Acta Geogr. Lodz., 24, 317-326.

Menzies, J. 1979. The mechanics of drumlin formation with particular reference to the change in pore-water content of the till. 7 . Glaciol., 22(87), 373-384.

Menzies, J. 1984. Drumlins: a bibliography. Norwich, Geo Books.

Miller, J. W., Jr. 1972. Variations in New York drumlins. Ann. Assoc. Am. Geogr., 62(3), 418-423.

Mooers, H. D. 1989. Drumlin formation: a time transgressive model. Boreas, $18(2), 99-107$.

Mooers, H.D. 1990. Ice-marginal thrusting of drift and bedrock: thermal regime, subglacial aquifers, and glacial surges. Can. 7 . Earth Sci., $27(6), 849-862$.

Moran, S. R. 1971. Glaciotectonic structures in drift. In Goldthwait, R.P., ed. Till: a symposium. Columbus, $\mathrm{OH}$, Ohio State University Press, 127-148.

Moran, S. R., L. Clayton, R. LeB. Hooke, M. M. Fenton and L. D. Andriashek. 1980. Glacier-bed landforms of the prairie region of North America. 7. Glaciol., 25(93), 457-476.

Morris, T. F. 1986. The dispersal trains of southeastern Prince of Wales Island, Northwest Territory, Canada: a contribution to the north-central Laurentide ice sheet. Boulder, CO, University of Colorado. Institute for Arctic and Alpine Research, 53-54. (15th Annual Arctic and Alpine Workshop Abstracts.)

Muller, E. H. 1963. Geology of Chautauqua County, New Yorkpart 2. N.Y. State Mus. Sci. Serv. Bull. 392.

Nayfeh, A. H. 1993. Introduction to perturbation techniques. New York, John Wiley and Sons.

Newman, W.A., R. C. Berg, P.S. Rosen and H. D. Glass. 1990. Pleistocene stratigraphy of the Boston Harbor drumlins, Massachusetts. Quat. Res., 34(2), 148-159.

Nye, J.F. 1953. The flow law of ice from measurements in glacier tunnels, laboratory experiments and the Jungfraufirn borehole experiment. Proc. R. Soc., Ser. A, 219 (1139), 477-489.

Patterson, C.J. 1989. Glaciological variables of drumlin formation. (M.Sc. thesis, University of Minnesota, Minneapolis.)

Piotrowski, J.A. and I. J. Smalley. 1987. The Woodstock drumlin field, southern Ontario, Canada. In Menzies, J. and J. Rose, eds. Drumlin
Symposium. Rotterdam, Balkema, 309-321.

Rabassa, J. 1987. Drumlins and drumlinoid forms in northern James Ross Island, Antarctic Peninsula. In Menzies, J. and J. Rose, eds. Drumlin Symposium. Rotterdam, Balkema, 267-288.

Riley, J. M. 1987. Drumlins of the southern Vale of Eden, Cumbria, England. In Menzies, J. and J. Rose, eds. Drumlin Symposium. Rotterdam, Balkema, 323-333.

Rõuk, A. -M. and A. Raukas. 1989. Drumlins of Estonia. Sediment. Geol., 62 (3-4), 371-384.

Schneider, A. F. 1961. Pleistocene geology of the Randall region, central Minnesota. Minn. Geol. Surv. Bull. 40.

Shaler, N.S. 1870. On the parallel ridges of drift in eastern Massachusetts, with some remarks on the glacial period. Proceedings of the Boston Society of Natural History, 13, 196-204.

Sharpe, D. R. 1987. The stratified nature of drumlins from Victoria Island and southern Ontario, Canada. In Menzies, J. and J. Rose, eds. Drumlin Symposium. Rotterdam, Balkema, 185-214.

Shaw, J. and D. Kvill. 1984. A glaciofluvial origin for drumlins of the Livingston Lake area, Saskatchewan. Can. f. Earth Sci., 21(12), 1442-1459.

Slater, G. 1929. The structure of drumlins on the south shore of Lake Ontario. N.Y. State Mus. Bull. 281, 3-19.

Stea, R. R. and Y. Brown. 1989. Variation in drumlin orientation, form and stratigraphy relating to successive ice flows in southern and central Nova Scotia. Sediment. Geol., 62(3-4), 223-240.

Upham, W. 1894a. Marine shells and fragments of shells in drumlins near Boston. Am. J. Sci., 3rd Series, 47, 238239.

Upham, W. 1894b. The Madison type of drumlins. American Geologist, 14, 69-83.

Upham, W. 1897. Drumlins containing or lying on modified drift. American Geologist, 20, 383-387.

Vernon, P. 1966. Drumlins and Pleistocene ice flow over the Ards Peninsula, Strangford Lough area, County Down, Ireland. $f$. Glaciol., 6(45), 401-409.

Waitt, R. B., Jr and R. M. Thorson. 1983. The Cordilleran ice sheet in Washington, Idaho, and Montana. In Wright, H. E., Jr and S. C. Porter, eds. Late Quaternary environments of the United States. Vol. 1. Minneapolis, MN, University of Minnesota Press, 53-70.

Whittecar, G. R. and D. M. Mickelson. 1979. Composition, internal structures, and an hypothesis of formation for drumlins, Waukesha County, Wisconsin, U.S.A. f. Glaciol., 22(87), 357-371.

Williams, R. B. G. 1975. The British climate during the last glaciation; an interpretation based on periglacial phenomena. In Wright, A. E. and F. Moseley, eds. Ice ages: ancient and modern. Liverpool, Seel House Press, 95-120.

Wright, H. E., Jr. 1957. Stone orientation in the Wadena drumlin field, Minnesota. Geogr. Ann., 39(1), 19-31.

Wright, H.E., Jr. 1962. Role of the Wadena lobe in the Wisconsin glaciation of Minnesota. Geol. Soc. Am. Bull., 73(1), 73-100.

Wright, H.E., Jr. 1973. Tunnel valleys, glacial surges, and subglacial hydrology of the Superior lobe, Minnesota. The Wisconsinan stage. Geol. Soc. Am. Mem. 136, 251-276.

Wright, H.E., Jr and W.A. Watts. 1969. Glacial and vegetational history of northeastern Minnesota. Minn. Geol. Surv. Spec. Publ. Ser. 11.

Wright, W.B. 1912. The drumlin topography of south Donegal. Geol. Mag., 9(4), 153-159. 